\title{
Approaches and Perspectives for Development of African Swine Fever Virus Vaccines
}

\author{
Marisa Arias ${ }^{1, *}$, Ana de la Torre ${ }^{1}$, Linda Dixon ${ }^{2}$, Carmina Gallardo ${ }^{1}$, Ferran Jori ${ }^{3}$ (D), \\ Alberto Laddomada ${ }^{4}$, Carlos Martins ${ }^{5}$, R. Michael Parkhouse ${ }^{6}$, Yolanda Revilla ${ }^{7}$, \\ Fernando Rodriguez ${ }^{8}$ and Jose-Manuel Sanchez-Vizcaino ${ }^{9}$
}

1 European Union Reference Laboratory for ASF, Centro de Investigación en Sanidad Animal (INIA-CISA), 28015 Madrid, Spain; torre@inia.es (A.D.L.T.); gallardo@inia.es (C.G.)

2 The Pirbright Institute (TPI), Surrey GU24 0NF, UK; linda.dixon@pirbright.ac.uk

3 ASTRE, University of Montpellier, CIRAD, INRA, F-34398 Montpellier, France ferran.jori@cirad.fr

4 Istituto Zooprofilattico Sperimentale della Sardegna (IZS-Sardegna), 07100 Sassari, Sardinia, Italy; albertolad@live.com

5 Faculdade de Medicina Veterinária (FMV-ULisboa), 1300-477 Lisbon, Portugal; cmartins@fmv.ulisboa.pt

6 Instituto Gulbenkian de Ciência (IGC), Rua Quinta Grande 6, 2780-156 Oeiras, Portugal;

parkhous@igc.gulbenkian.pt

7 Centro de Biología Molecular Severo Ochoa (CBMSO-CSIC-UAM), C/ Nicolás Cabrera nº 1,

Campus de Cantoblanco, 28049 Madrid, Spain; yrevilla@cbm.csic.es

8 Institute for Research and Technology Food and Agriculture (IRTA), Centre de Recerca en Sanitat Animal (CReSA, IRTA-UAB), Campus de la Universitat Autònoma de Barcelona, 08193 Bellaterra, Spain; fernando.rodriguez@irta.es

9 OIE Reference Laboratory for ASF, Centro de Vigilancia Sanitaria Veterinaria (VISAVET), Universidad Complutense de Madrid, Avda. Puerta del Hierro, 28040 Madrid, Spain; jmvizcaino@ucm.es

* Correspondence: arias@inia.es; Tel.: +34-916-202-300

Academic Editor: Alexander Zakhartchouk

Received: 1 September 2017; Accepted: 3 October 2017; Published: 7 October 2017

\begin{abstract}
African swine fever (ASF) is a complex disease of swine, caused by a large DNA virus belonging to the family Asfarviridae. The disease shows variable clinical signs, with high case fatality rates, up to $100 \%$, in the acute forms. ASF is currently present in Africa and Europe where it circulates in different scenarios causing a high socio-economic impact. In most affected regions, control has not been effective in part due to lack of a vaccine. The availability of an effective and safe ASFV vaccines would support and enforce control-eradication strategies. Therefore, work leading to the rational development of protective ASF vaccines is a high priority. Several factors have hindered vaccine development, including the complexity of the ASF virus particle and the large number of proteins encoded by its genome. Many of these virus proteins inhibit the host's immune system thus facilitating virus replication and persistence. We review previous work aimed at understanding ASFV-host interactions, including mechanisms of protective immunity, and approaches for vaccine development. These include live attenuated vaccines, and "subunit" vaccines, based on DNA, proteins, or virus vectors. In the shorter to medium term, live attenuated vaccines are the most promising and best positioned candidates. Gaps and future research directions are evaluated.
\end{abstract}

Keywords: African swine fever; vaccine; immunology; vaccine gaps

\section{Introduction}

African swine fever virus (ASFV) is the cause of African swine fever (ASF), an important disease affecting both wild and domestic swine of all breeds and ages. In domestic pigs and wild boar, ASF is associated with a number of clinical manifestations including a hyper-acute or acute disease with 
very high mortality rates [1-3]. Subacute forms, which result in reduced mortality of 30 to $70 \%$, as well as sub-clinical or chronic disease forms which can result in very low if any mortality, have also been described [4]. Infection has been long established in wild suids in Africa, including warthogs and bushpigs, causing long unapparent infections. These mammalian hosts, together with invertebrate Ornithodoros ticks, can act as natural ASFV reservoirs in some areas of the sub-Saharan Africa, acting as a permanent source of ASF virus for domestic pigs. ASFV is commonly transmitted when unexposed pig populations (domestic or wild) have direct contact with blood, excretions, secretions, meat, or carcasses from infected animals or indirect contact with infected products. ASF notification is mandatory because of the great sanitary and socio-economic impact on the pig industry, which include bans on international trade in live animals and swine products.

ASFV is the unique member of the family Asfarviridae. The virus genome is double-stranded DNA and virions have a characteristic icosahedral capsid assembled on an internal membrane and surrounding a nucleoprotein core. An additional membrane is derived from the plasma membrane as virus buds from cells, both intracellular [5-7]. Intracellular mature and extracellular enveloped forms of the virion are infectious [8,9]. The DNA genome shows significant variations in length from 170 to $193 \mathrm{kbp}$ depending on the isolate, thus coding for between 150 and 167 open reading frames (ORFs) [10-14], specifying the 54 structural proteins of the ASFV particle and more than 100 infection proteins [15]. On the basis of molecular genotyping, 23 distinct genotypes of ASFV have been described to date. All genotypes are present in sub-Saharan Africa, while only genotype I and genotype II have spread outside Africa. ASFV genotype I spread to the Iberian Peninsula in 1957 and 1960, with later incursions into some other European countries, the Caribbean, and Brazil, and still remaining in Sardinia. Genotype II spread from East Africa to the Caucasus region in 2007 and then spread rapidly and widely throughout the Russian Federation and a number of countries in Eastern Europe.

ASF epidemiology is complex and depends on the characteristics of the virus circulating, the presence of wild and domestic hosts and reservoirs of infection, and on environmental, social, and cultural factors. After years in some regions, mortality rates of pigs have been observed to decline over time, to become subacute, chronic, or subclinical forms of the disease caused by the emergence of moderate and low virulent virus isolates. These variable clinical forms can be difficult to recognize and may persist in surviving pigs, providing a potential reservoir for infection. Survivors from sub-acute infections were shown to shed virus from their oropharynx for at least 70 days [16-18]. Virus can also be isolated from porcine tissues for up to 180 days post infection [19-22]. Thus, contaminated, uncooked pig meat swill fed to pigs and movement of infected animals are common routes for virus transmission.

ASF is present in twenty-eight sub-Saharan African countries, and in Sardinia, Italy since 1978 [23,24]. Following an increased epidemic in sub-Saharan countries, in 2007 ASFV spread far beyond its historical limits, first to Georgia $[25,26]$ and now reported in the Caucasus region, north-west and central Russian Federation, Belarus, Moldova, and some eastern EU countries (Lithuania, Poland Estonia, Latvia, Czech Republic, and Romania). Effective control of ASF has not been achieved in Africa or Europe, providing a serious threat to the global pig industry.

No vaccine is available against ASF. Prevention, control, and eradication measures are mainly based on early detection by efficient laboratory diagnosis and on the implementation of strict sanitary measures [27]. Vaccination to contain viral infections in livestock is generally regarded as the most cost efficient measure if available. These facts, combined with the re-emergence of ASF in the European Continent have increased interest in the development of a vaccine against ASF as an additional control tool. The availability of effective and safe ASF vaccines would improve ASF disease control and eradication programs thus reducing economic losses in the endemic regions. Work leading to the rational development of a protective ASF vaccine is therefore a priority. This review describes previous and current strategies to develop effective and safe vaccines for ASFV. Future prospects are also evaluated. 


\section{Immune Response against ASFV}

Understanding the intricacies of protective immunity to ASFV is a key issue for vaccine development. However, this is still poorly characterized. Nevertheless, it is clear that pigs that recover from infection are resistant to challenge against some ASFV isolates, indicating that these animals can develop a protective immune response [28-37]. However, the complexity of ASFV, a virus encoding more than 160 different polypeptides, many of them specialized in evading different aspects of the immune system [38], together with the variability of the virus isolates so far identified has complicated this task.

Attenuated ASF viruses obtained by tissue-culture adaptation conferred solid protection against parental virulent viruses, but did not confer protection against heterologous viruses, including against ASFV isolates found in close geographical ad temporal proximity [31,39]. Similarly, several investigations have shown that animals that survive infection with less virulent isolates can be protected against challenge with related virulent viruses [28,40,41]. The extent of cross-protection against different genotypes has been little studied, although there are reports of cross-protection between certain genotypes [36,42-45]. Currently, the virus antigens important for cross-protection have not been fully characterized, although the virus CD2v-like protein has been suggested to be a candidate [42,45-47].

Considerable difficulties have been encountered while searching for immune correlates of protection. Nevertheless, it seems clear that the protective immune response includes both cellular and serological immunity $[32,33,35,37,48,49]$. Some findings, such as the lack of fully neutralizing antibodies, remain controversial [50]. However, evidence for some role of antibody-mediated immunity in protection has been obtained. Thus, passive transfer of sera from ASFV-infected and recovered pigs partially protected pigs against homologous (parental) ASFV challenge infection and the potential fatal consequences of infection by delaying the onset of the ASF clinical signs and reducing the levels of viremia [51-55].

A variety of in vivo and in vitro studies indicate potentially protective roles of antibodies by additional mechanisms including complement mediated cell lysis or antibody-dependent cell-mediated cytotoxicity (ADCC) [37,50,56-61]. An interesting correlation has been established between the presence of haemadsorption (HAD) inhibitory antibodies in a serum with its capacity to inhibit the infection of ASFV in vitro and to partially protect against ASFV challenge in vivo [42,62].

Evidence also indicates a key role for NK cells [63] and specific $\mathrm{T}$ cell responses in protection $[33,35,63]$. Using pigs recovered from experimental infection with the naturally attenuated ASFV-isolate NHVNon Haemadsorbing Portugal 68 (NHP68) as an experimental model, the key protective role of the CD8-T cell subset in virus elimination as a result of cytotoxic activity was observed [33]. Antibody depletion of the $\mathrm{CD}^{+}$cell population abrogated the protection induced by the natural attenuated strain OURT88/3, demonstrating an essential role for this cell subset in protection [35]. In conclusion, evidence available indicates that immune protection involves antibody-mediated and cell-mediated mechanisms.

\section{Proteins Involved in Immune Evasion and Virulence}

A better understanding of virus-host interactions is required for vaccine development. Important objectives that would help to define rational vaccine approaches are the identification of host cell receptors and the virus proteins interacting with these, improved knowledge on virus mechanisms to overcome the protective host barriers inhibiting virus replication, and of the host immune mechanisms involved in protection.

The ASFV targets are mainly macrophages. These cells have an extremely important role in activating and orchestrating the immune response against virus infections [64,65]. ASFV uses a number of strategies to evade the host's defense systems, including innate and intrinsic immune mechanisms such as type I interferon (IFN) responses, apoptosis, inflammation, and the activation of specific target genes during ASFV infection, [66,67]. Identifying the key genes and their corresponding 
proteins mediating such processes is of great importance in understanding virus-host interactions and is fundamental for the design an effective live-attenuated vaccine.

Some progress towards the characterization of such virus "host evasion" genes has been made. For example, the non-essential A238Lp, which prevents transcriptional activation of host immune response genes by inhibiting host transcription factors. Several virus proteins are known to regulate and inhibit programmed cell death pathways at early times of infection. These include the non-essential proteins A179Lp, a Bcl-2 family member, A224Lp, Inhibitor of Apoptosis (IAP) family member, and C-type lectin EP153Rp. This allows virus replication and production of progeny virus to proceed. In contrast, other proteins such as the essential structural protein p54/E183Lp, may modulate the production of virus particles and the mechanisms of release by inducing apoptosis at late times of infection. The DP71Lp protein recruits protein phosphatase 1 to dephosphorylate translation initiation factor eIF2 and restore global protein synthesis. Several proteins are involved in inhibiting the induction of IFN including those coded for by the multigene family (MGF) 360 and 505 genes and the I329L, K205R, and A276R genes [67-84]. The I329Lp protein has been characterized as a glycoprotein localizing in the host cell surface membranes and was the first ASFV protein demonstrated to inhibit the IFN response through the Toll-like Receptor 3 (TLR3) signaling pathway [71]. In addition, I329Lp also inhibits TLR4 signaling. The K205Rp protein was shown to localize in the cytoplasm and to inhibit activation of IFN- $\beta$. The A276Rp protein was also identified as an inhibitor of IFN- $\beta$ activation, and does not appear to target IRF-7. As a consequence of the inhibition of IFN $\alpha \beta$, expression of the hundreds of IFN stimulated genes is inhibited. These have broad functions involved in activating an antiviral state in infected and bystander cells and activating host immune responses. The D96Rp (also referred to as UK) protein is also a potential immune evasion gene, although its mechanism of action is unclear [85]. Other modulatory proteins include the hemmaglutinin CD2v/E402Rp protein that is present on the surface of extracellular virions and inhibits activation of lymphocytes, [86-88]. These mentioned genes are good candidate targets for the development of an attenuated gene deletion mutant virus for vaccine development.

Finally, some essential ASFV proteins have been characterized, including ASFV-Toposoimerase II [89-91], a histone-like protein [92], and the ASFV-E2 Ubiquitin conjugating enzyme, opening new avenues to generate effective single-cycle mutant virus vaccines using helper cell lines expressing these essential proteins. Similar approaches have been reported for Bluetongue disease [93-95] and African horse sickness [96,97]. Both gene deletion attenuated and replication deficient viruses have the advantage of presenting almost the entire virus repertoire via Major histocompatibility complex (MHC) class I and II to CD8 and CD4 T cells, respectively, thus stimulating both cellular and serological immunity.

\section{Virus Proteins Important for Inducing Protective Antibody Responses}

Identification of virus proteins which may be targets of antibody mediating neutralization or elimination still merits more investigation. Virus proteins present on the surface of both intracellular mature and extracellular enveloped infectious virions and the surface of infected cells are expected to be important proteins for antibody-mediated protection (see Figure 1). Virus targets for neutralization have been identified including p72/B646Lp, p54/E183Lp, and p30/CP204Lp. Antibodies against p72/B646Lp and p54/E183Lp inhibited virus binding to cells, whereas those against p30/CP204Lp inhibited virus internalization. Other virion proteins present on the surface of intracellular mature or extracellular enveloped virus particles may be targets for neutralization by preventing virus entry or spread. These include the CD2v/EP402R protein, p12,/O61Rp, D117L proteins [42,50,58,98-100].

The characterization of cell receptors on pig macrophages is of interest in order to identify virus and host molecules involved in virus entry as targets to inhibit this process. These molecules may also include intracellular host proteins. For example, cellular proteins involved in virus release from endosomes to the cytoplasm or transport within the cytoplasm may be important $[101,102]$. 
The CD2v/EP402Rp interaction with the cellular adaptor AP-1 may be involved in movement of the viral particle, and thus have consequences for virulence and immune escape [101].

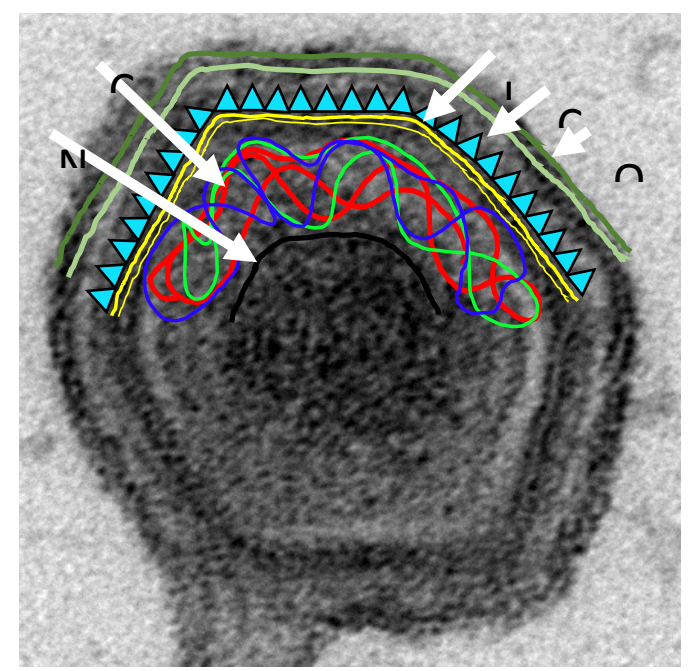

Figure 1. African swine fever virus (ASFV) structure. An electro micrograph of an extracellular ASFV particle budding through the cell plasma membrane is shown. The particle is large $(\sim 200 \mathrm{~nm})$ and complex containing more than 50 proteins. Several layers are indicated on the cartoon. The nucleoprotein core (NU) is surrounded by the core shell (CS) and the inner envelope (IE) on which the icosahedral capsid (CA) is assembled. This intracellular mature particle is assembled in cytoplasmic virus factories. The extracellular virus particles gain an additional outer envelope (OE) budding through the cells plasma membrane. The OE contains ASFV proteins, CD2v/EP402Rp, $\mathrm{p} 12 / \mathrm{O} 61 \mathrm{Rp}$ and the cellular protein designated p24; the CA contains major protein p72/B646Lp and also E120Rp, B438Lp; the IE contains p17/D117Lp, p54/E183Lp, E248Rp and p12/O61Rp; CS contains the cleavage products of polyproteins pp220/CP2475Lp (p150, p37, p34, p14) and pp62/CP530Rp (p35, p15) and S273Rp; the NU contains p10/K78Rp, 104Lp, proteins and enzymes required to initiate infection including the virus RNA polymerase as well as the virus genome.

Antibodies that inhibit virus spread would also be useful. Studies on the mechanisms of viral entry showed that ASFV uses macropinocytosis [103] and other mechanisms, including clathrin mediated endocytosis to enter porcine macrophages [104].

A rational identification of potential protective serological determinants of protective immunity (by screening of a virus expression library with a polyclonal antisera from a domestic pig surviving infection with virulent virus strain) identified fourteen serological immunodeterminants, including virus proteins B602Lp, C44Lp, CP312Rp, E183Lp, K145Rp, and K205Rp, as well as the structural proteins A104Rp, p10/K78Rp, p30/CP204Lp, p54/E183Lp, p72/B646Lp, and the non-structural proteins ribonucleotide reductase (F334Lp, F778Rp), DNA ligase (NP419Lp), and Thymidine kinase (K169Rp) [105].

\section{Virus Proteins Important for Inducing T Cell Mediated Immunity}

There is strong evidence for an important role for specific CD8 ${ }^{+} \mathrm{T}$ cells in protection $[35,106]$. By DNA immunization of pigs, partial protection against ASFV was demonstrated in the absence of specific antibodies, correlating with the induction of specific $\mathrm{CD}^{+} \mathrm{T}$ cells against the CD2v (hemagglutinin) $[107,108]$. DNA vaccination with a plasmid library identified multiple cytotoxic T lymphocyte (CTL) epitopes with protective potential [37]. Further work is required to characterize relevant antigenic epitopes, and complications arising from variability of MHC peptide presentation within outbred pig population. 
CTL determinants have been described before in the G1340Lp protein [109] and in the ASFV p30/CP204Lp and p72/B646Lp structural proteins [110,111], but their role in protection has not been demonstrated. Identification of ASFV CTL epitopes relevant for protection is a complicated issue due to the heterogeneity of the T cell population [34].

In addition to CD8 T cells, other subsets of T cells might play an important role in protection [37]. A deeper understanding on the role of T cells as well as NK and other cells from the innate immune system should facilitate formulating optimal subunit vaccine formulations in the future.

\section{Approaches towards ASFV Vaccine Development}

ASFV vaccine development has been investigated since the 1960s. Approaches used have included inactivated viruses, recombinant proteins/peptides, viral vectors for antigen delivery, and live-attenuated vaccines. As of yet, none of these experimental approaches have been taken forward for evaluation of their potential for commercial production.

\subsection{Inactivated Candidate Vaccines}

To date, inactivated preparations of ASFV have not conferred protection even in the presence of adjuvants, a not entirely surprising finding if cellular immunity is essential for protection. In addition the possibility of antibody-mediated enhancement of the infection has been observed [112-116]. The complexity of the virus particle which contains more than fifty proteins in several layers and the fact that there are two infectious forms, an intracellular mature and extracellular form, might additionally contribute to this failure in conferring protection since effective virus neutralization is difficult to achieve in primary infections.

\subsection{Subunit Vaccine Approaches}

ASFV encodes up to 167 proteins making it very difficult to select candidate antigens that can induce protection for incorporation in subunit vaccines. As described above, several ASFV proteins have been reported to be targets for virus neutralization and the potential for these proteins to induce protection has been tested.

While co-immunization of pigs with p54 and p30 expressed in baculovirus conferred significant protection against lethal challenge with E75 [98], a combination of p54 + p30 + p72 baculovirus expressed proteins did not protect against lethal challenge with the pathogenic Malawi isolate [100]. These contradictory results might be partially explained by the virus strain used, albeit more recent work with DNA vaccines encoding p54 and p30 did not induce neutralizing antibodies or show any protection against lethal infection with E75 [117]. However, these results are difficult to compare due to the very different nature of protein versus DNA immunization protocols. In a different study, the $\mathrm{CD} 2 \mathrm{v} / \mathrm{EP} 402 \mathrm{R}$ gene, when expressed in a baculovirus system, induced some degree of protection against a challenge with virulent virus. This correlated with the induction of antibodies that inhibited haemadsorbtion (HAD) and temporarily inhibited infection [62]. Recent evidence indicates that $\mathrm{CD} 2 \mathrm{v} / \mathrm{EP} 402 \mathrm{R}$ and/or C-type lectin/EP153R proteins may be important for protection against ASFV infection [42].

DNA vaccination has also been used to identify potentially protective antigens. Immunization of pigs with a gene fusion of p30/CP204L and /p54/E183L, with the gene for a single chain variable fragment of a specific antibody against swine leukocyte antigen II, induced ASFV specific $\mathrm{T}$ cells. However, neither neutralizing antibodies nor protection against a virulent challenge was reported [107]. Fusion of gene fragment coding for the extracellular domain of HA (CD2v/EP402R) fused to the Lp30/CP204L and p54/E183L genes enhanced both humoral and cellular responses in pigs, without conferring protection. However, fusion of these three ASFV-genes (CD2v/EP402R, p54/E183L and p30/CP204L) to the ubiquitin gene, induced strong CTL responses and conferred partial protection in the absence of specific antibodies. This protection correlated with the proliferation of HA (CD2v /EP402R)-specific CD8 ${ }^{+}$T cells [117]. Further immunization with a DNA expression 
library containing several other viral ORFs fused to ubiquitin also conferred partial protection against a virulent challenge [108]. Once again, this protection correlated with the induction of ASFV specific T cells and the absence of detectable antibodies, highlighting the role of $\mathrm{T}$ cell responses in protection and revealing the existence of multiple ASFV antigens with potential protective capacity. Despite the utility that these strategies might have in the future for dissecting both the immune mechanisms and the ASFV-antigens involved in protection, they are today far from providing the level of protection required to be useful in the field.

Prime-boost strategies have been carried out using combinations of specific ASFV recombinant proteins and DNA but no protection against challenge with Armenia strain was observed despite induction of robust immune responses [118]. Table 1 summarizes the current approaches for development of subunit protein or DNA vaccines.

Table 1. Approaches for development of subunit protein or DNA vaccines.

\begin{tabular}{cccc}
\hline Genes/Proteins Delivered & Type of Vaccine & Challenge & Reference \\
\hline p54/E183L, p30/CP204L & Baculovirus expressed proteins & Partial protection & {$[98]$} \\
P54/E183L, p30/CP204L, p72/B646L & Baculovirus expressed proteins & No protection & {$[100]$} \\
CD2v/pEP402R & Baculovirus expressed proteins & Partial protection & {$[62]$} \\
p54/E183L, p30/CP204L & DNA vaccination & No protection & {$[107,117]$} \\
Ubiquitin-CD2v/pEP402R- & DNA vaccination & Partial protection & {$[117]$} \\
p54/E183L-p30/CP204L & DNA vaccination & Partial protection & {$[108]$} \\
DNA expression library & & & \\
\hline
\end{tabular}

Immunization of pigs with pools of recombinant adenoviruses expressing individual ASFV proteins and boosted with either the same vectors [119] or with recombinant modified vaccinia Ankara strain (MVA) expressing the same antigens [120] also induced robust cellular and antibody responses although pigs were not challenged with ASFV [119,120].

Further work will be needed in order to identify both the antigens to be included in a potential subunit vaccine and the optimal immune mechanisms to be triggered after vaccination in order to confer solid protection against ASFV. Optimal delivery systems for immunization of pigs also need to be identified.

\subsection{Live Attenuated Vaccines (LAVs)}

\subsubsection{LAVs Obtained from Virulent and Naturally Occurring Low Virulent ASFV Isolates}

The use in the field of LAVs produced by the attenuation of naturally occurring virulent strains has been limited to the extensive experience in Portugal and Spain during the early 1960s [121]. At that time, a large number of animals were vaccinated with LAVs in field conditions, in which animals were exposed to multiple infections and re-infections with circulating field strains viruses by different routes and probably including exposure to infected soft ticks. Vaccinations under these conditions led to the appearance of chronic forms of ASF [122]. From the field experiment in Spain, some animals showed chronic clinical signs. These vaccines are not used anymore mainly due to safety problems derived from their inherent infectious nature [123].

Other experimental strategies have involved the immunization of pigs with the naturally attenuated ASFV strains OURT88/3 or NH/P68. Immunized pigs were protected against challenge with related virulent strains $[35,40,42,63]$, and partial cross-protection has been shown against heterologous viruses [42-46]. The protection levels varied from $66 \%$ to $100 \%$ dependent on the pigs and the challenge virus, as well as the delivery route and administration dose $[36,40,43,44,89]$. As described for the subunit vaccines, both specific antibodies [53] and specific CD8 ${ }^{+} \mathrm{T}$ cells [35], seem to play a crucial role in the protection afforded by LAVs. Cross-protection induced by the OURT88/3 isolate against challenge with virulent isolates from different genotypes was correlated with the ability of those isolates to specifically stimulate IFN $\gamma$-producing lymphocytes from the immunized pigs [36]. 
Despite the correlation between the induction of specific T cell responses and protection $[36,37,108]$, this is far from being a confirmed prediction and other immune mechanisms are under investigation to identify key players in protection. However, the attempts using these naturally attenuated ASFV strains as vaccines have so far demonstrated several side-effects, at least at certain doses, since a substantial proportion of the vaccinated pigs developed unacceptable post-vaccination reactions including pneumonia, locomotor disturbances, necrotic foci, abortion, and death. In the best scenario, pigs do not show significant clinical signs with the exception of transient fever and low viremia that coincides with low nasal shedding in some vaccinated pigs $[43,44,63]$.

\subsubsection{Recombinant LAVs Obtained from Virulent Viruses}

Recombinant ASFVs containing specific deletions of genes, such as the thymidine kinase (TK) gene, could yield non-pathogenic viruses $[45,81,124]$. In addition, depletion of genes involved in the evasion of the immune response, NL (alternatively named DP71L) gene, and multiple members of multigene families 360 and 505 (MGF 360/505), or genes involved in virus replication or morphogenesis and 9GL (B119L) gene, have resulted in attenuation of virulent ASFV isolates and induction of protective immune responses against virulent parental virus challenge, but with varying levels of residual virulence [125-128]. However, the effects of gene deletion on ASFV attenuation and the induction of protection may be strain dependent and, in some cases, the deleted viruses exhibit a virulence phenotype indistinguishable from the parental virus. For example, the deletion of the NL (DP71L) gene from virulent strains completely attenuates the European E70 strain in animals but had no effect in two African ASFV strains [127-129]. Additionally, ASFV strains Malawi and Georgia are both attenuated by deletion of the thymidine kinase (TK) gene but only the TK-deleted Malawi virus was capable of inducing a protective immune response in inoculated animals [124].

Recent studies have demonstrated that multiple-gene mutants in ASFVs can variably affect viral immunogenicity. The multiple deletion of 6 members of MGF360 and 505 combined with the 9GL gene produced an attenuated Georgia ASFV strain with improved safety, but was unable to confer protection to animals when challenged with the virulent parental virus [130]. In contrast, the virulent Georgia isolate modified by deletion of the 9GL and DP96R/UK virulence factors showed improved safety and protection compared to the deletion of 9GL alone [131]. These results clearly demonstrated that the serial deletion of a second virulence factor might produce safer recombinant live attenuated ASFV-vaccines, thus opening hopes for future work.

The BA71 genotype I isolate with the CD2v/EP402R (HA) gene deleted [45] induced protection in pigs challenged with the homologous (parental) virulent ASFV BA71 strain and against the heterologous virulent genotype I E75, and genotype II Georgia07 ASFV strain [34]. Combining some of the different mutations so far described might yield a vaccine prototype with potential field applications.

\subsubsection{Recombinant LAVs Obtained from Attenuated Viruses}

Several strategies to improve safety of attenuated strains (OURT88/3 or NH/P68) by deletion of several genes have provided variable results. The deletion of genes such as DP71L and DP96R (involved in virulence and clinical signs), or the A276R (an inhibitor of IFN), reduced the ability of the attenuated viruses to protect against challenge [132]. In contrast, some of these mutants showed a good degree of protection (60-100\%) against challenge with the virulent strain Armenia 2007. In agreement with previous studies, however, the vaccine candidates induced (low) viremia and side-effects such as arthritis and necrotic foci in most of the vaccinated pigs $[43,44]$, which would prevent their commercial use. The main antiviral response, type I IFN, is critical for the virus attenuation and induction of protection. However, it is critical to achieve a balance such that efficient viral replication occurs to induce an effective immune response but avoid clinical signs [44,130,131]. 


\subsubsection{Cell Lines for Production of LAVS}

Primary porcine macrophage and monocyte culture systems are used in laboratories for biological and immunological studies of ASFV. However, primary cells would be unlikely to be used in vaccine production due batch to batch variations and the laborious and costly methods to obtain cells from animal donors. These issues were partially overcome by the adaptation of some ASFV isolates to grow in different stable monkey cell lines, such as Vero or MS cells, which have been routinely used for biological studies, production, and purification of the adapted virus [133-135]. However, the adaptation of ASF viruses has always resulted in genomic changes to the point of reducing the virus replication in pigs such that protection is not achieved [136]. In relation to this, five different porcine cell lines of monocyte origin have been developed so far: ZMAC, IPAM WT, IPAM-CD163, WSL, and $\mathrm{C} \Delta 2+$ [137-141]. In addition, the COS-cell line has shown to be highly efficient to sustain the "in vitro" replication of ASF viruses with little apparent adaptation [135,142,143]. The genetically modified $\mathrm{LAV}$, the BA71 CD2 produced in COS cells, yielded an effective vaccine able to confer homologous and heterologous protection. The COS cell line was successfully used for the generation of the LAV without significant genome changes [45]. However, some "in vivo" experimental studies based on the attenuated NH/P68 strain have shown that the LAV produced in COS cells were unable to maintain the capacity to confer protection [144]. Therefore, further evaluation studies are required for the potential use of COS cells in vaccine production. Furthermore, no studies have been published so far determining the behavior of ASFV strains generated from cell lines such as WSL and COS-1.

\section{Development of DIVA Test}

The application of a vaccine is dependent on the availability of an accompanying discriminatory test (DIVA test) allowing differentiation between vaccinated and infected animals. In order to ensure proper monitoring of the vaccination campaign and of its impact on disease evolution in a vaccinated pigs, the vaccine will need both a positive and a negative marker to reliably differentiate between vaccinated animals and those naturally infected. Reliable DIVA tests should therefore be considered in parallel to vaccine development and adapted to the context of vaccinating farmed (injected administration) and free-ranging populations of suids (oral administration).

These tests might be relatively easy to design for either subunit vaccines or LAVs. The latter could be based on those genes that are deleted to provide a DIVA test based on a negative marker. The negative marker (e.g., virulence or IFN inhibitor genes) would first need to be evaluated for induction of antibodies in the non-vaccinated, infected animals which would be absent from the vaccinated animals. A positive selection could be used since markers present in the genome of manipulated strains (BGal, BGus, others), facilitate the discrimination between vaccine and natural strains using molecular or serological methods.

\section{ASFV Vaccine Candidates Likely to Be Available in the Shortest Term}

From the currently available data on vaccine development, the LAVs seem the most promising candidates in the short-term. The solid protection so far demonstrated by a number of LAVs (up to $100 \%$ ), the increased safety achieved by making multiple gene deletions together with their potential to confer solid cross-protection, support optimism about their potential for field implementation in the medium term. Table 2 summarizes the most promising LAV candidates for vaccine development based on existing data/knowledge. In spite of their experimental success, further research is needed to confirm their safety, DIVA-capabilities, and efficacy in long-term controlled experiments; an essential requisite to offer optimal LAVs.

Research performed to develop ASFV subunit vaccines suggest greater caution regarding their prompt commercial implementation. In contrast to their intrinsic safer nature and DIVA-potential, the protection levels afforded against ASFV experimental challenge have been poor when compared with 
LAVs. A continuous research effort focused both on antigen discovery and on better understanding the mechanisms involved in ASFV protection should succeed in the longer-term.

Table 2. Promising progress towards the development of a ASFV LAV.

\begin{tabular}{|c|c|c|c|c|c|}
\hline Parental ASFV & Vaccine Type & ASFV Vaccine & Cell Production System & PROTECTION & References \\
\hline NH/P68 (att) & $\begin{array}{l}\text { Naturally } \\
\text { attenuated }\end{array}$ & NHV/P68 & PBM & $\begin{array}{l}\text { Heterologous strain } \\
\text { (L60, ARM07) }\end{array}$ & {$[44,63]$} \\
\hline OURT88/3 (att) & $\begin{array}{l}\text { Naturally } \\
\text { attenuated }\end{array}$ & OURT $88 / 3$ & BM & $\begin{array}{c}\text { Homologous/ } \\
\text { heterologous strain } \\
\text { (OURT88/1, UG65) }\end{array}$ & {$[31,36,124]$} \\
\hline Georgia07 (vir) & $\begin{array}{l}\text { Genetically } \\
\text { modified }\end{array}$ & Georgia07 $\triangle 9$ GL\&DP96R/UK & PAM & Homologous strain & [126] \\
\hline Ba71 (vir) & $\begin{array}{l}\text { Genetically } \\
\text { modified }\end{array}$ & $\mathrm{Ba} 71 \triangle \mathrm{CD} 2 / \mathrm{EP} 402 \mathrm{R}$ & $\cos$ & $\begin{array}{l}\text { Homologous and } \\
\text { heterologous strain } \\
\text { (E75, GEORGIA07) }\end{array}$ & [88] \\
\hline Benin (vir) & $\begin{array}{l}\text { Genetically } \\
\text { modified }\end{array}$ & Benin $\triangle \mathrm{MGF}$ & BM & Homologous strain & [130] \\
\hline Benin (vir) & $\begin{array}{l}\text { Genetically } \\
\text { modified }\end{array}$ & Benin $\triangle \mathrm{DP} 148 \mathrm{R}$ & BM & Homologous strain & [130] \\
\hline NH/P68 (att) & $\begin{array}{l}\text { Genetically } \\
\text { modified }\end{array}$ & $\mathrm{NH} / \mathrm{P} 68 \Delta \mathrm{A} 238 \mathrm{~L}$ & COS +4 passages in PAM & $\begin{array}{l}\text { Homologous and } \\
\text { heterologous strain } \\
\text { (ARM07) }\end{array}$ & [43] \\
\hline
\end{tabular}

\section{Expert Commentary}

Progress on ASFV vaccine development requires further research on virus biology and virus-host interactions at all levels. Research gaps include transcriptome analysis to identify those virus genes that are transcribed at different stages of the replication cycle, and a better knowledge of the virus structural proteins, particularly those on the virion surface. In addition, better knowledge of virus entry mechanisms, including the cell receptor(s) on pig macrophages, will identify targets for vaccine development. Further definition of the functions of ASFV proteins, in particular those that inhibit the host's defenses, is needed to optimize development of LAVs.

The mechanisms involved in immune protection against ASFV are still poorly characterized. Evidence indicates that adaptive immune responses required to protect against ASFV involve both serological and cellular immunity. Host immune and/or concomitant co-pathogen infection status appear to impact ASFV virulence. Research in the mechanisms by which the natural hosts, including bushpig and warthog, resist ASFV disease may help to identify the key actors involved in protection to develop ASFV vaccines. However, we should keep in mind that these African wild pigs belong to different species than domestic pigs and wild boar. Stocks of these wild African species of suids available for experimentation and therefore adapted to live in captive conditions are not available and zoological gardens are reluctant to provide individuals for animal experimentation. Therefore, building up collections of warthogs and bushpigs for vaccine research should be an instrumental preliminary step to investigate the mechanisms and processes involved in the natural protection of wild African pigs against ASFV.

Due to those constraints, some experts consider the efforts should be focused on pigs as the target species of interest. Preliminary in vitro tests are absolutely necessary (e.g., continued ability to replicate in pig macrophages for LAV). Identification of the correlates of immune protection in vitro as well as in vivo would help to evaluate the induction of protection against challenge and reduce unnecessary painful challenges with ASFV. Although not required for vaccine registration, knowledge of correlates of protection can also assist in monitoring vaccine efficacy and reduce the costs of vaccine testing.

For wild boar populations, potential candidate vaccines need to be immunogenic after oral administration and this will probably require a higher virus titer in the vaccine. In addition, the oral vaccine needs to be stable in the external environment to avoid losing potency when it is exposed to low and hot temperatures, sunshine, and other environmental factors. Another consideration is that the bait needs to be designed to allow uptake and attractiveness for animals of all ages and at different seasons. For a feasible oral immunization scheme, a suitable delivery device in the form of 
bait is needed, as it has been successfully experience with oral vaccination campaigns of wild boars against Classical Swine Fever $[145,146]$.

\subsection{Gaps and Future Directions for LAVs}

Despite recent successes in the use of LAVs, there are still some important gaps and uncertainties that should be considered. LAVs have been demonstrated to confer solid protection (up to $100 \%$ surviving) against ASFV experimental challenge. However, the safety of ASF LAVs is of crucial importance. For vaccine registration, safety and immunogenicity has to be established over a range of doses and safety of repeated administration and overdose should be investigated.

It is also necessary to establish the genetic stability of LAVs during culture in vitro and pig passage in vivo. Lack of recombination in vaccination experiments with wild type challenge virus should be established. Multiple deletions in one single LAV candidate should reduce this possibility to the minimum. Since resources are limited and the costs of completing all experiments required for vaccine registration are very costly, it will be important to establish a pipeline for evaluation of LAV candidates which will enable early selection of the best candidates to be taken forward for further evaluation. Ideally this would include some selection at the stage of cell culture. Identifying correlates of in vitro pathogenesis and ability to induce protection is therefore important.

Other gaps are related to the selection of targeted virulence genes to be deleted. However, it is not always clear which virulence genes to target, since the effects of gene deletion on ASFV attenuation and protection can be strain dependent. Thus, testing gene deleted viruses from different genotypes may be needed to obtain strains that provide protection against isolates circulating in different regions. Further work is required to optimize the combinations of genes that can be deleted to produce a LAV that can meet safety standards required for registration and induce a good level of protection.

Another important issue unresolved is the availability of a licensed cell line to grow the LAVs for vaccine production. Some success using candidate established cell lines has been reported but more work is needed to optimize commercial productions systems.

\subsection{Gaps and Future Directions for Subunit Vaccines}

The subunit vaccine candidates also require further work. Several ASFV proteins have been associated with protection, but no specific viral protein(s) has been shown to be sufficient to confer full robust protective immunity in pigs. Thus, it is likely that additional antigens with protective potential will be identified and that a small pool of these that can induce high levels of protection will be defined. Previous studies [105] demonstrated that inactivated virions did not protect against infection. In addition, optimized delivery/vector systems are required to induce good levels of immune responses. Several immunization strategies and delivery/vector systems have been used to immunize pigs with a variety of different ASFV antigens. Results from these experiments are difficult to compare and interpret since the antigens or the delivery/vector system may not be optimal to induce a protective immune response. Further work is required to define protective antigens and to optimize delivery systems and strategies for vaccination to induce protective responses. Eventually, systems that can be applied in the field commercially will also need to be defined. Viral vectors that can deliver several antigens/genes should be investigated. Finally, the possibility of inducing "enhancing" antibody responses should be kept in mind.

\subsection{Programs for Vaccine Candidate Evaluation}

The development of new vaccines is dependent upon robust preclinical animal models in order to select those vaccine candidates which should progress to clinical development. The design of programmes to evaluate vaccine candidates in experimental conditions should be prepared according to the requirements of the European veterinary immunological legislation guidelines [http:/ / www.ema.europa.eu/ema/index.jsp?curl=pages/regulation/general/general_cont ent_000374.jsp\&mid=WC0b01ac058002ddc5], taking into account the critical requirements for vaccine 
registration in the EU such as target species (swine, wild boar), categories (young/older animals, pregnant), routes of the vaccine administration, animal welfare for the in vivo experiments, vaccine dose (depending on vaccination schedule proposed), standardized clinical data collection and analysis (techniques, target samples, etc), routes of infection, challenge doses, challenge virus strain/s to be used, vaccination period and safety studies (including absence of reversion to virulence), and environmental risk assessment (capacity of the virus to survive, establish, and disseminate and pathogenicity to other live organisms).

The gaps identified mainly revolve around two aspects: (i) to harmonize and standardize clinical data collection and analysis and, (ii) to reduce the size, lengths, and costs of clinical trials. A critical deficiency is still the absence of a reliable "in vitro" correlation of "in vivo" protection. Thus, the only unarguable proof for an antigen or LAV to become a real vaccine candidate comes from its potential to clinically protect the target species (pigs and wild boar). This is considered one of the major challenges to progress in ASF vaccine development since there is no animal model other than swine. Safety experiments using LAVs need long experiments with a large number of animals. Vaccines are tested and selected using vaccination-challenge experiments in pigs which require strict biosafety level 3 (BSL3) animal facilities. Such procedures are not only extremely expensive, but are also environmentally and ethically difficult, considering the moderate to severe animal suffering associated with disease development, and the requirement that all animals be slaughtered at the end of the experimentation.

According to the European legislation, the guidelines for immunological veterinary medicines, following the in vivo laboratory tests, the efficacy and safety of the future vaccines should be evaluated by field trials. Field trials are a key point to evaluate the risk-benefit of vaccine candidates. Their design will depend on the characteristics of the vaccine (DIVA vaccine, formulation) and the infection under different virus-host scenarios (different virulence, different densities of hosts, and different durations of viremia and probabilities of developing chronic infections).

\section{Conclusions}

The recent alarming spread of ASF in Eastern Europe demands immediate countermeasures, with development of a vaccine as an important priority and as an additional good tool accompanying sanitary control measures.

Considerable progress has been made in the last decade leading to the development of ASF attenuated strains that have the potential to be used as candidate vaccines in a short/medium term. However, there are a number of important issues to clarify before a LAV is available for commercial development. Further in vivo testing with existing candidate LAVs to confirm acceptable levels of safety and efficacy against relevant field strains is a mandatory step and ensuring safety is curerntly the major challenge for its field implementation. More studies are needed to develop in vitro correlates of protection to facilitate selection of the most promising vaccine candidates and reduce the number of animal challenge experiments. In addition, for LAV production, identifying a suitable cell line is a priority.

The development of an efficient vaccine based on individual determinants from the ASFV (subunit vaccine) also requires parallel research efforts. In contrast to LAVs, subunit vaccines present the advantage of their innocuous nature, however, they would require a long-term effort in terms of research on protective antigen discovery and effective delivery mechanisms.

For the use of any type of vaccine in the field a DIVA test should be developed in parallel.

In principle, the same vaccine strain could be designed for domestic pigs and wild boar. Natural populations of wild boar have been effectively vaccinated against other infectious diseases through the use of LAVs administered orally by the distribution of palatable baits. However, the development of a specific vaccine to be successfully used in the wild boar will probably pose additional challenges related to vaccine administration route, efficacy, safety, its use in the environment, and monitoring immunity in natural populations. In both cases, domestic pig and wild boar, the vaccine should be orientated to give a response to the growing threat of ASF and directly combat the epidemic situation. For this purpose, field managing vaccination plans should be designed based on risk assessment 
strategies to effectively control the disease according to the different epidemiological scenarios present in Africa and Eastern Europe, and to reduce the threat and the possibility of ASF introduction into disease-free regions.

Acknowledgments: This review have been promoted and supported by European Commision Directorate-General SANTE, Health and Food Safety, throughout the European Union Reference Laboratory Grant 2016-2017. We thank Pippa Hawes, for providing Electron Microscopy.

Author Contributions: Authors, in alphabetic order, have contributed as equals as EU expert working group on "ASFV vaccine Blueprint and Roadmap". This manuscript is based on the "African Swine Fever vaccine Blueprint and Roadmap" previously prepared by consensus expert opinion of all the authors available at: https:/ / ec.europa.eu/food/sites/food/files/safety/docs/cff_animal_vet-progs_asf_blue-print-road-map.pdf. L.D., C.G. and M.A. wrote the main draft of this manuscript; All the authors improved the draft; L.D., M.A. C.G., M.P., F.R. made final improvements for its definitive publication.

Conflicts of Interest: The authors declare no conflict of interest.

\section{References}

1. Blome, S.; Gabriel, C.; Beer, M. Pathogenesis of African swine fever in domestic pigs and European wild boar. Virus Res. 2013, 173, 122-130. [CrossRef] [PubMed]

2. Gabriel, C.; Blome, S.; Malogolovkin, A.; Parilov, S.; Kolbasov, D.; Teifke, J.P.; Beer, M. Characterization of African swine fever virus Caucasus isolate in European wild boars. Emerg. Infect. Dis. 2011, 17, 2342-2345. [CrossRef] [PubMed]

3. Pietschmann, J.; Guinat, C.; Beer, M.; Pronin, V.; Tauscher, K.; Petrov, A.; Keil, G.; Blome, S. Course and transmission characteristics of oral low-dose infection of domestic pigs and European wild boar with a Caucasian African swine fever virus isolate. Arch. Virol. 2015, 160, 1657-1667. [CrossRef] [PubMed]

4. Sánchez-Vizcaíno, J.M.; Mur, L.; Gomez-Villamandos, J.C.; Carrasco, L. An update on the epidemiology and pathology of african swine fever. J. Comp. Pathol. 2015, 152, 9-21. [CrossRef] [PubMed]

5. Schloer, G.M. Polypeptides and structure of African swine fever virus. Virus Res. 1985, 3, 295-310. [CrossRef]

6. Andrés, G.; García-Escudero, R.; Viñuela, E.; Salas, M.L.; Rodríguez, J.M. African swine fever virus structural

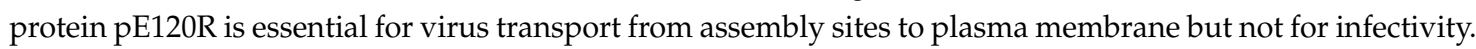
J. Virol. 2001, 75, 6758-6768. [CrossRef] [PubMed]

7. Hawes, P.C.; Netherton, C.L.; Wileman, T.E.; Monaghan, P. The envelope of intracellular African swine fever virus is composed of a single lipid bilayer. J. Virol. 2008, 82, 7905-7912. [CrossRef] [PubMed]

8. Andres, G.; Alejo, A.; Simon-Mateo, C.; Salas, M.L. African swine fever virus protease, a new viral member of the SUMO-1-specific protease family. J. Biol. Chem. 2001, 276, 780-787. [CrossRef] [PubMed]

9. Breese, S.S., Jr.; Pan, I.C. Electron microscopic observation of African swine fever virus development in Vero cells. J. Gen. Virol. 1978, 40, 499. [CrossRef] [PubMed]

10. De Villiers, E.P.; Gallardo, C.; Arias, M.; da Silva, M.; Upton, C.; Martin, R.; Bishop, R.P. Phylogenomic analysis of 11 complete African swine fever virus genome sequences. Virology 2010, 400, 128-136. [CrossRef] [PubMed]

11. Chapman, D.A.; Tcherepanov, V.; Upton, C.; Dixon, L.K. Comparison of the genome sequences of non-pathogenic and pathogenic African swine fever virus isolates. J. Gen. Virol. 2008, 89, 397-408. [CrossRef] [PubMed]

12. Chapman, D.A.; Darby, A.C.; Da Silva, M.; Upton, C.; Radford, A.D.; Dixon, L.K. Genomic analysis of highly virulent Georgia 2007/1 isolate of African swine fever virus. Emerg. Infect. Dis. 2011, 17, 599-605. [CrossRef] [PubMed]

13. Portugal, R.; Coelho, J.; Hoper, D.; Little, N.S.; Smithson, C.; Upton, C.; Martins, C.; Leitao, A.; Keil, G.M. Related strains of African swine fever virus with different virulence: Genome comparison and analysis. J. Gen. Virol. 2015, 96, 408-419. [CrossRef] [PubMed]

14. Bishop, R.P.; Fleischauer, C.; de Villiers, E.P.; Okoth, E.A.; Arias, M.; Gallardo, C.; Upton, C. Comparative analysis of the complete genome sequences of Kenyan African swine fever virus isolates within p72 genotypes IX and, X. Virus. Genes. 2015, 50, 303-309. [CrossRef] [PubMed]

15. Dixon, L.K.; Chapman, D.A.; Netherton, C.L.; Upton, C. African swine fever virus replication and genomics. Virus Res. 2013, 173, 3-14. [CrossRef] [PubMed] 
16. De Carvalho Ferreira, H.C.; Weesendorp, E.; Elbers, A.R.; Bouma, A.; Quak, S.; Stegeman, J.A.; Loeffen, W.L. African swine fever virus excretion patterns in persistently infected animals: A quantitative approach. Vet. Microbiol. 2012, 160, 327-340. [CrossRef] [PubMed]

17. De Carvalho Ferreira, H.C.; Weesendorp, E.; Quak, S.; Stegeman, J.A.; Loeffen, W.L. Quantification of airborne African swine fever virus after experimental infection. Vet. Microbiol. 2013, 165, 243-251. [CrossRef] [PubMed]

18. De Carvalho Ferreira, H.C.; Backer, J.A.; Weesendorp, E.; Klinkenberg, D.; Stegeman, J.A.; Loeffen, W.L. Transmission rate of African swine fever virus under experimental conditions. Vet. Microbiol. 2013, 165, 296-304. [CrossRef] [PubMed]

19. Allaway, E.C.; Chinombo, D.O.; Edelsten, R.M.; Hutchings, G.H.; Sumption, K.J. Serological study of pigs for antibody against African swine fever virus in two areas of southern Malawi. Rev. Sci. Tech. 1995, 14, 667-676. [CrossRef] [PubMed]

20. Arias, M.; Sánchez-Vizcaíno, J.M. African swine fever eradication: The Spanish model. In Trends in Emerging Viral Infections of Swine, 1st ed.; Morilla, A., Jin, K., Zimmerman, J., Eds.; Iowa State University Press: Ames, IA, USA, 2002; pp. 133-139.

21. Arias, M.; Sánchez-Vizcaíno, J.M. African swine fever. In Diseases of Swine, 10th ed.; Zimmerman, J., Karriker, L.A., Ramirez, A., Schwartz, K.J., Stevenson, G.W., Eds.; John Wiley and Sons: New York, NY, USA, 2012; pp. 396-404.

22. Gallardo, C.; Soler, A.; Nieto, R.; Sánchez, M.A.; Martins, C.; Pelayo, V.; Carrascosa, A.; Revilla, Y.; Simón, A.; Briones, V.; et al. Experimental transmission of African Swine Fever (ASF) low virulent isolate NH/P68 by surviving pigs. Transbound. Emerg. Dis. 2015, 62, 612-622. [CrossRef] [PubMed]

23. Penrith, M.L.; Vosloo, W.; Jori, F.; Bastos, A.D. African swine fever virus eradication in Africa. Virus Res. 2013, 173, 228-246. [CrossRef] [PubMed]

24. Sánchez-Vizcaíno, J.M.; Mur, L.; Martínez-López, B. African Swine Fever: An epidemiological update. Transbound. Emerg. Dis. 2012, 59 (Suppl. 1), 27-35. [CrossRef] [PubMed]

25. Rowlands, R.J.; Michaud, V.; Heath, L.; Hutchings, G.; Oura, C.; Vosloo, W.; Dwarka, R.; Onashvili, T.; Albina, E.; Dixon, L.K. African swine fever virus isolate, Georgia, 2007. Emerg. Infect. Dis. 2008, 14, 1870-1874. [CrossRef] [PubMed]

26. Food and Agriculture Organization; United Nations. African swine fever in the Russian Federation: Risk factors for Europe and beyond. EMPRES Watch 2013, 28. Available online: http:/ / www.fao.org/docrep/018 /aq240e/aq240e.pdf (accessed on 2 September 2013).

27. European Commission, Health and Consumers Directorate-Dene (7138/2013). Guidelines on Surveillance and Control of African Swine Fever in Feral Pigs and Preventive Measures for Pig Holdings. Available online: http:/ / ec.europa.eu/food/animal/diseases/controlmeasures/docs/sanco_7138_2013_asf_wb_en .pdf (accessed on 1 October 2017).

28. DETRAY, DE. Persistence of viremia and immunity in African swine fever. Am. J. Vet. Res. 1957, 18, 811-816. [PubMed]

29. MALMQUIST, WA. Serologic and immunologic studies with African swine fever virus. Am. J. Vet. Res. 1963, 24, 450-459. [PubMed]

30. Sanchez-Vizcaino, J.M.; Slauson, D.O.; Ruiz-Gonzalvo, F.; Valero, F. Lymphocyte function and cell-mediated immunity in pigs with experimentally induced African swine fever. Am. J. Vet. Res. 1981, 42, 1335-1341. [PubMed]

31. Ruiz Gonzalvo, F.; Carnero, M.E.; Bruyel, V. 1983. Immunological responses of pigs to partially attenuated African swine fever virus and their resistance to virulent homologous and heterologous viruses. In African Swine Fever; Wilkinson, P.J., Ed.; EUR 8466 EN, Proceedings of CEC/FAO Research Seminar: Sardinia, Italy, 23-25 September 1981; pp. 206-216.

32. Scholl, T.; Lunney, J.K.; Mebus, C.A.; Duffy, E.; Martins, C.L. Virus-specific cellular blastogenesis and interleukin-2 production in swine after recovery from African swine fever. Am. J. Vet. Res. 1989, 50, 1781-1786. [PubMed]

33. Martins, C.L.; Lawman, M.J.; Scholl, T.; Mebus, C.A.; Lunney, J.K. African swine fever virus specific porcine cytotoxic T cell activity. Arch. Virol. 1993, 129, 211-225. [CrossRef] [PubMed] 
34. Jenson, J.S.; Childerstone, A.; Takamatsu, H.; Dixon, L.K.; Parkhouse, R.M. The cellular immune recognition of proteins expressed by an African swine fever virus random genomic library. J. Immunol. Methods 2000, 242, 33-42. [CrossRef]

35. Oura, C.A.; Denyer, M.S.; Takamatsu, H.; Parkhouse, R.M. In vivo depletion of CD8+ T lymphocytes abrogates protective immunity to African swine fever virus. J. Gen. Virol. 2005, 86 Pt 9, 2445-2450. [CrossRef] [PubMed]

36. King, K.; Chapman, D.; Argilaguet, J.M.; Fishbourne, E.; Hutet, E.; Cariolet, R.; Hutchings, G.; Oura, C.A.; Netherton, C.L.; Moffat, K.; et al. Protection of European domestic pigs from virulent African isolates of African swine fever virus by experimental immunisation. Vaccine 2011, 29, 4593-4600. [CrossRef] [PubMed]

37. Takamatsu, H.H.; Denyer, M.S.; Lacasta, A.; Stirling, C.M.; Argilaguet, J.M.; Netherton, C.L.; Oura, C.A.; Martins, C.; Rodríguez, F. Cellular immunity in ASFV responses. Virus Res. 2013, 173, 110-121. [CrossRef] [PubMed]

38. Dixon, L.K.; Abrams, C.C.; Bowick, G.; Goatley, L.C.; Kay-Jackson, P.C.; Chapman, D.; Liverani, E.; Nix, R.; Silk, R.; Zhang, F. African swine fever virus proteins involved in evading host defence systems. Vet. Immunol. Immunopathol. 2004, 100, 117-134. [CrossRef] [PubMed]

39. Lacasta, A.; Monteagudo, P.L.; Jiménez-Marín, Á.; Accensi, F.; Ballester, M.; Argilaguet, J.; Galindo-Cardiel, I.; Segalés, J.; Salas, M.L.; Domínguez, J.; et al. Live attenuated African swine fever viruses as ideal tools to dissect the mechanisms involved in viral pathogenesis and immune protection. Vet. Res. 2015, 20, 135. [CrossRef] [PubMed]

40. Boinas, F.S.; Hutchings, G.H.; Dixon, L.K.; Wilkinson, P.J. Characterization of pathogenic and non-pathogenic African swine fever virus isolates from Ornithodoros erraticus inhabiting pig premises in Portugal. J. Gen. Virol. 2004, 85 Pt 8, 2177-2187. [CrossRef] [PubMed]

41. Mulumba-Mfumu, L.K.; Goatley, L.C.; Saegerman, C.; Takamatsu, H.H.; Dixon, L.K. Immunization of African Indigenous Pigs with Attenuated Genotype I African Swine Fever Virus OURT88/3 Induces Protection Against Challenge with Virulent Strains of Genotype, I. Transbound. Emerg. Dis. 2016, 63, e323-e327. [CrossRef] [PubMed]

42. Burmakina, G.; Burmakina, G.; Malogolovkin, A.; Tulman, E.R.; Zsak, L.; Delhon, G.; Diel, D.G.; Shobogorov, N.M.; Morgunov, Y.P.; Morgunov, S.Y.; et al. African swine fever virus serotype-specific proteins are significant protective antigens for African swine fever. J. Gen. Virol. 2016, 97, 1670-1675. [CrossRef] [PubMed]

43. Carmina, G.; Alejandro, S.; Angel, C.; Elena, S.; Raquel, N.; Alicia, S.; Miguel, S.; Carlos, M.; Victor, B.; Yolanda, R.; et al. In vivo testing of deletion mutants as candidate vaccines for African swine fever in vaccination/challenge models in pigs. In Proceedings of the 9th Annual Meeting EPIZONE, Montpellier, France, 2-3 September 2015.

44. Carmina, G.; Alejandro, S.; Raquel, N.; Lina, M.; Covadonga, P.; Virginia, P.; Carlos, M.; José, M.; Sánchez-Vizcaino; Marisa, A. Protection of European domestic pigs from Armenia virulent African swine fever virus by experimental immunisation using the attenuated and non-haemadsorbing African swine fever virus isolate ASFV/NH/P68. In Proceedings of the IX International Congress of Veterinary Virology (ESVV), Madrid, Spain, 4-7 September 2012.

45. Paula, L.; Monteagudo; Anna, L.; Elisabeth, L.; Laia, B.; Javier, C.; Sonia, P.-P.; Florencia, C.-F.; Francesc, A.; María, J.N. BA71 $\triangle \mathrm{CD} 2$ : A new recombinant live attenuated African swine fever virus with cross-protective capabilities. J. Virol. 2017. [CrossRef]

46. Malogolovkin, A.; Burmakina, G.; Tulman, E.R.; Delhon, G.; Diel, D.G.; Salnikov, N.; Kutish, G.F.; Kolbasov, D.; Rock, D.L. African swine fever virus CD2v and C-type lectin gene loci mediate serological specificity. J. Gen. Virol. 2015, 96, 866-873. [CrossRef] [PubMed]

47. Malogolovkin, A.; Burmakina, G.; Titov, I.; Sereda, A.; Gogin, A.; Baryshnikova, E.; Kolbasov, D. Comparative analysis of African swine fever virus genotypes and serogroups. Emerg. Infect. Dis. 2015, 21, 312-315. [CrossRef] [PubMed]

48. Revilla, Y.; Pena, L.; Viñuela, E. Interferon-gamma production by African swine fever virus-specific lymphocytes. Scand. J. Immunol. 1992, 35, 225-230. [CrossRef] [PubMed]

49. Martin, C.L.; Leitao, A.C. Porcine immune responses to African swine fever virus (ASFV) infection. Vet. Immunol. Immunopathol. 1994, 43, 99-106. [CrossRef] 
50. Escribano, J.M.; Galindo, I.; Alonso, C. Antibody-mediated neutralization of African swine fever virus: Myths and facts. Virus Res. 2013, 173, 101-109. [CrossRef] [PubMed]

51. Schlafer, D.H.; Mebus, C.A.; McVicar, J.W. African swine fever in neonatal pigs: Passively acquired protection from colostrum or serum of recovered pigs. Am. J. Vet. Res. 1984, 45, 1367-1372. [PubMed]

52. Schlafer, D.H.; McVicar, J.W.; Mebus, C.A. African swine fever convalescent sows: Subsequent pregnancy and the effect of colostral antibody on challenge inoculation of their pigs. Am. J. Vet. Res. 1984, 45, 1361-1366. [PubMed]

53. Onisk, D.V.; Borca, M.V.; Kutish, G.; Kramer, E.; Irusta, P.; Rock, D.L. Passively transferred African swine fever virus antibodies protect swine against lethal infection. Virology 1994, 198, 350-354. [CrossRef] [PubMed]

54. De Boer, C.J. Studies to determine neutralizing antibody in sera from animals recovered from African swine fever and laboratory animals inoculated with African virus with adjuvants. Arch. Gesamte Virusforsch 1967, 20, 164-179. [CrossRef] [PubMed]

55. Ruiz Gonzalvo, F.; Carnero, M.E.; Caballero, C.; Martínez, J. Inhibition of African swine fever infection in the presence of immune sera in vivo and in vitro. Am. J. Vet. Res. 1986, 47, 1249-1252. [PubMed]

56. Wardley, R.C.; Norley, S.G.; Wilkinson, P.J.; Williams, S. The role of antibody in protection against African swine fever virus. Vet. Immunol. Immunopathol. 1985, 9, 201-212. [CrossRef]

57. Ruiz Gonzalvo, F.; Caballero, C.; Martinez, J.; Carnero, M.E. Neutralization of African swine fever virus by sera from African swine fever-resistant pigs. Am. J. Vet. Res. 1986, 47, 1858-1862. [PubMed]

58. Zsak, L.; Onisk, D.V.; Afonso, C.L.; Rock, D.L. Virulent African swine fever virus isolates are neutralized by swine immune serum and by monoclonal antibodies recognizing a 72-Kda viral protein. Virology 1993, 196, 596-602. [CrossRef] [PubMed]

59. Borca, M.V.; Irusta, P.; Carrillo, C.; Afonso, C.L.; Burrage, T.; Rock, D.L. African swine fever virus structural protein P72 contains a conformational neutralizing epitope. Virology 1994, 201, 413-418. [CrossRef] [PubMed]

60. Gomez-Puertas, P.; Oviedo, J.M.; Rodriguez, F.; Coll, J.; Escribano, J.M. Neutralization susceptibility of African swine fever virus is dependent on the phospholipid composition of viral particles. Virology 1997, 228, 180-189. [CrossRef] [PubMed]

61. Rock, D.L. Challenges for African swine fever vaccine development-“ " . perhaps the end of the beginning”. Vet. Microbiol. 2016, 206, 52-58. [CrossRef] [PubMed]

62. Ruiz-Gonzalvo, F.; Rodríguez, F.; Escribano, J.M. Functional and immunological properties of the baculovirus-expressed hemagglutinin of African swine fever virus. Virology 1996, 218, 285-289. [CrossRef] [PubMed]

63. Leitão, A.; Cartaxeiro, C.; Coelho, R.; Cruz, B.; Parkhouse, R.M.; Portugal, F.; Vigário, J.D.; Martins, C.L. The non-haemadsorbing African swine fever virus isolate ASFV/NH/P68 provides a model for defining the protective anti-virus immune response. J. Gen. Virol. 2001, 82 Pt 3, 513-523. [CrossRef] [PubMed]

64. Gordon, S.; Clarke, S.; Greaves, D.; Doyle, A. Molecular immunobiology of macrophages: Recent progress. Curr. Opin. Immunol. 1995, 7, 24-33. [CrossRef]

65. Van Furth, R.; Cohn, Z.A.; Hirsch, J.G.; Humphrey, J.H.; Spector, W.G.; Langevoort, H.L. Mononuclear phagocytic system: New classification of macrophages, monocytes and of their cell line. Bull. World Health Organ. 1972, 47, 651-658. [PubMed]

66. Sánchez, E.G.; Quintas, A.; Nogal, M.; Castelló, A.; Revilla, Y. African swine fever virus controls the host transcription and cellular machinery of protein synthesis. Virus Res. 2013, 173, 58-75. [CrossRef] [PubMed]

67. Correia, S.; Ventura, S.; Parkhouse, R.M. Identification and utility of innate immune system evasion mechanisms of ASFV. Virus Res. 2013, 173, 87-100. [CrossRef] [PubMed]

68. Borca, M.V.; O’Donnell, V.; Holinka, L.G.; Rai, D.K.; Sanford, B.; Alfano, M.; Carlson, J.; Azzinaro, P.A.; Alonso, C.; Gladue, D.P. The Ep152R ORF of African swine fever virus strain Georgia encodes for an essential gene that interacts with host protein BAG6. Virus Res. 2016, 223, 181-189. [CrossRef] [PubMed]

69. Golding, J.P.; Goatley, L.; Goodbourn, S.; Dixon, L.K.; Taylor, G.; Netherton, C.L. Sensitivity of African swine fever virus to type I interferon is linked to genes within multigene families 360 and 505. Virology 2016, 493, 154-161. [CrossRef] [PubMed]

70. Correia, S.; Ventura, S. Goodbourn RME Parkhouse, M. ASFV includes several mechanisms for the manipulation of IFN responses. Cytokine 2013, 63, 256. [CrossRef]

71. De Oliveira, V.L.; Almeida, S.C.; Soares, H.R.; Crespo, A.; Marshall-Clarke, S.; Parkhouse, R.M. A novel TLR3 inhibitor encoded by African swine fever virus (ASFV). Arch. Virol. 2011, 156, 597-609. [CrossRef] [PubMed] 
72. Granja, A.G.; Sánchez, E.G.; Sabina, P.; Fresno, M.; Revilla, Y. African swine fever virus blocks the host cell antiviral inflammatory response through a direct inhibition of PKC-theta-mediated p300 transactivation. J. Virol. 2009, 83, 969-980. [CrossRef] [PubMed]

73. Granja, A.G.; Perkins, N.D.; Revilla, Y. A238L inhibits NF-ATc2, NF-kappa, B.; and c-Jun activation through a novel mechanism involving protein kinase C-theta-mediated up-regulation of the amino-terminal transactivation domain of p300. J. Immunol. 2008, 180, 2429-2442. [CrossRef] [PubMed]

74. Rivera, J.; Abrams, C.; Hernáez, B.; Alcázar, A.; Escribano, J.M.; Dixon, L.; Alonso, C. The MyD116 African swine fever virus homologue interacts with the catalytic subunit of protein phosphatase 1 and activates its phosphatase activity. J. Virol. 2007, 81, 2923-2929. [CrossRef] [PubMed]

75. Afonso, C.L.; Piccone, M.E.; Zaffuto, K.M.; Neilan, J.; Kutish, G.F.; Lu, Z.; Balinsky, C.A.; Gibb, T.R.; Bean, T.J.; Zsak, L.; et al. African swine fever virus multigene family 360 and 530 genes affect host interferon response. J. Virol. 2004, 78, 1858-1864. [CrossRef] [PubMed]

76. Rodríguez, C.I.; Nogal, M.L.; Carrascosa, A.L.; Salas, M.L.; Fresno, M.; Revilla, Y. African swine fever virus IAP-like protein induces the activation of nuclear factor kappa, B. J. Virol. 2002, 76, 3936-3942. [CrossRef] [PubMed]

77. Zsak, L.; Lu, Z.; Burrage, T.G.; Neilan, J.G.; Kutish, G.F.; Moore, D.M.; Rock, D.L. African swine fever virus multigene family 360 and 530 genes are novel macrophage host range determinants. J. Virol. 2001, 75, 3066-3076. [CrossRef] [PubMed]

78. Nogal, M.L.; González de Buitrago, G.; Rodríguez, C.; Cubelos, B.; Carrascosa, A.L.; Salas, M.L.; Revilla, Y. African swine fever virus IAP homologue inhibits caspase activation and promotes cell survival in mammalian cells. J. Virol. 2001, 75, 2535-2543. [CrossRef] [PubMed]

79. Miskin, J.E.; Abrams, C.C.; Dixon, L.K. African swine fever virus protein A238L interacts with the cellular phosphatase calcineurin via a binding domain similar to that of NFAT. J. Virol. 2000, 74, 9412-9420. [CrossRef] [PubMed]

80. Lewis, T.; Zsak, L.; Burrage, T.G.; Lu, Z.; Kutish, G.F.; Neilan, J.G.; Rock, D.L. An African swine fever virus ERV1-ALR homologue, 9GL, affects virion maturation and viral growth in macrophages and viral virulence in swine. J. Virol. 2000, 74, 1275-1285. [CrossRef] [PubMed]

81. Moore, D.M.; Zsak, L.; Neilan, J.G.; Lu, Z.; Rock, D.L. The African swine fever virus thymidine kinase gene is required for efficient replication in swine macrophages and for virulence in swine. J. Virol. 1998, 72, 10310-10315. [PubMed]

82. Revilla, Y.; Cebrián, A.; Baixerás, E.; Martínez, C.; Viñuela, E.; Salas, M.L. Inhibition of apoptosis by the African swine fever virus Bcl-2 homologue: Role of the BH1 domain. Virology 1997, 228, 400-404. [CrossRef] [PubMed]

83. Neilan, J.G.; Lu, Z.; Kutish, G.F.; Zsak, L.; Burrage, T.G.; Borca, M.V.; Carrillo, C.; Rock, D.L. A BIR motif containing gene of African swine fever virus, $4 \mathrm{CL}$, is nonessential for growth in vitro and viral virulence. Virology 1997, 230, 252-264. [CrossRef] [PubMed]

84. Brun, A.; Rodríguez, F.; Escribano, J.M.; Alonso, C. African swine fever virus gene A179L, a viral homologue of bcl-2, protects cells from programmed cell death. Virology 1996, 225, 227-230. [CrossRef] [PubMed]

85. Zsak, L.; Caler, E.; Lu, Z.; Kutish, G.F.; Neilan, J.G.; Rock, D.L. A nonessential African swine fever virus gene UK is a significant virulence determinant in domestic swine. J. Virol. 1998, 72, 1028-1035. [PubMed]

86. Borca, M.V.; Carrillo, C.; Zsak, L.; Laegreid, W.W.; Kutish, G.F.; Neilan, J.G.; Burrage, T.G.; Rock, D.L. Deletion of a CD2-like gene, 8-DR, from African swine fever virus affects viral infection in domestic swine. J. Virol. 1998, 72, 2881-2889. [PubMed]

87. Reis, A.L.; Netherton, C.; Dixon, L.K. Unraveling the Armor of a Killer: Evasion of Host Defenses by African Swine Fever Virus. J. Virol. 2017, 91. [CrossRef] [PubMed]

88. Fernando, R.; Maria, L.S. CD2 Deficient African Swine Fever Virus as Live Attenuated or Subsequently Inactivated Vaccine against African Swine Fever in Mammals. WO 2015091322 A1 (PCT/EP2014/077688, US20150165018). 18 June 2015.

89. Coelho, J.; Ferreira, F.; Martins, C.; Leitão, A. Functional characterization and inhibition of the type II DNA topoisomerase coded by African swine fever virus. Virology 2016, 493, 209-216. [CrossRef] [PubMed]

90. Coelho, J.; Martins, C.; Ferreira, F.; Leitão, A. African swine fever virus ORF P1192R codes for a functional type II DNA topoisomerase. Virology 2015, 474, 82-93. [CrossRef] [PubMed] 
91. Freitas, F.B.; Frouco, G.; Martins, C.; Leitão, A.; Ferreira, F. In vitro inhibition of African swine fever virus-topoisomerase II disrupts viral replication. Antiviral Res. 2016, 134, 34-41. [CrossRef] [PubMed]

92. Frouco, G.; Freitas, F.B.; Coelho, J.; Leitão, A.; Martins, C.; Ferreira, F. DNA-Binding Properties of African Swine Fever Virus pA104R, a Histone-Like Protein Involved in Viral Replication and Transcription. J. Virol. 2017, 91. [CrossRef] [PubMed]

93. Celma, C.C.; Stewart, M.; Wernike, K.; Eschbaumer, M.; Gonzalez-Molleda, L.; Breard, E.; Schulz, C.; Hoffmann, B.; Haegeman, A.; De Clercq, K.; et al. Replication-Deficient Particles: New Insights into the Next Generation of Bluetongue Virus Vaccines. J. Virol. 2017. [CrossRef] [PubMed]

94. Matsuo, E.; Celma, C.C.; Boyce, M.; Viarouge, C.; Sailleau, C.; Dubois, E.; Bréard, E.; Thiéry, R.; Zientara, S.; Roy, P. Generation of Replication-Defective Virus-Based Vaccines That Confer Full Protection in Sheep against Virulent Bluetongue Virus Challenge. J. Virol. 2011, 85, 10213-10221. [CrossRef] [PubMed]

95. Feenstra, F.; Pap, J.S.; van Rijn, P.A. Application of bluetongue Disabled Infectious Single Animal (DISA) vaccine for different serotypes by VP2 exchange or incorporation of chimeric VP2. Vaccine 2015, 33, 812-818. [CrossRef] [PubMed]

96. Van Gennip, R.G.; van de Water, S.G.; Potgieter, C.A.; van Rijn, P.A. Structural protein VP2 of African horse sickness virus is not essential for virus replication in vitro. J. Virol. 2017. [CrossRef] [PubMed]

97. Van de Water, S.G.; van Gennip, R.G.; Potgieter, C.A.; Wright, I.M.; van Rijn, P.A. VP2 Exchange and NS3/NS3a Deletion in African Horse Sickness Virus (AHSV) in Development of Disabled Infectious Single Animal Vaccine Candidates for AHSV. J. Virol. 2015, 89, 8764-8772. [CrossRef] [PubMed]

98. Gómez-Puertas, P.; Rodríguez, F.; Oviedo, J.M.; Brun, A.; Alonso, C.; Escribano, J.M. The African swine fever virus proteins p54 and p30 are involved in two distinct steps of virus attachment and both contribute to the antibody-mediated protective immune response. Virology 1998, 243, 461-471. [CrossRef] [PubMed]

99. Gómez-Puertas, P.; Rodríguez, F.; Oviedo, J.M.; Ramiro-Ibáñez, F.; Ruiz-Gonzalvo, F.; Alonso, C.; Escribano, J.M. Neutralizing antibodies to different proteins of African swine fever virus inhibit both virus attachment and internalization. J. Virol. 1996, 70, 5689-5694. [PubMed]

100. Neilan, J.G.; Zsak, L.; Lu, Z.; Burrage, T.G.; Kutish, G.F.; Rock, D.L. Neutralizing antibodies to African swine fever virus proteins p30, p54, and p72 are not sufficient for antibody-mediated protection. Virology 2004, 319, 337-442. [CrossRef] [PubMed]

101. Pérez-Núñez, D.; García-Urdiales, E.; Martínez-Bonet, M.; Nogal, M.L.; Barroso, S.; Revilla, Y.; Madrid, R. $\mathrm{CD} 2 \mathrm{v}$ interacts with adaptor protein AP-1 during African swine fever infection. PLoS ONE 2015, 10, e0123714. [CrossRef] [PubMed]

102. Muñoz-Moreno, R.; Cuesta-Geijo, M.A.; Martínez-Romero, C.; Barrado-Gil, L.; Galindo; García-Sastre, A.; Alonso, C. Antiviral Role of IFITM Proteins in African Swine Fever Virus Infection. PLoS ONE 2016, 11, e0154366.

103. Sánchez, E.G.; Quintas, A.; Pérez-Núñez, D.; Nogal, M.; Barroso, S.; Carrascosa, Á.L.; Revilla, Y. African swine fever virus uses macropinocytosis to enter host cells. PLoS Pathog. 2012, 8, e1002754. [CrossRef] [PubMed]

104. Hernaez, B.; Alonso, C. Dynamin- and clathrin-dependent endocytosis in African swine fever virus entry. J. Virol. 2010, 84, 2100-2109. [CrossRef] [PubMed]

105. Kollnberger, S.D.; Gutierrez-Castañeda, B.; Foster-Cuevas, M.; Corteyn, A.; Parkhouse, R.M. Identification of the principal serological immunodeterminants of African swine fever virus by screening a virus cDNA library with antibody. J. Gen. Virol. 2002, 83, 1331-1342. [CrossRef] [PubMed]

106. Oura, C.A.; Powell, P.P.; Anderson, E.; Parkhouse, R.M. The pathogenesis of African swine fever in the resistant bushpig. J. Gen. Virol. 1998, 79, 1439-1443. [CrossRef] [PubMed]

107. Argilaguet, J.M.; Pérez-Martín, E.; Nofrarías, M.; Gallardo, C.; Accensi, F.; Lacasta, A.; Mora, M.; Ballester, M.; Galindo-Cardiel, I.; López-Soria, S.; et al. DNA vaccination partially protects against African swine fever virus lethal challenge in the absence of antibodies. PLOS ONE 2012, 7, e40942. [CrossRef] [PubMed]

108. Lacasta, A.; Ballester, M.; Monteagudo, P.L.; Rodríguez, J.M.; Salas, M.L.; Accensi, F.; Pina-Pedrero, S.; Bensaid, A.; Argilaguet, J.; López-Soria, S.; et al. Expression library immunization can confer protection against lethal challenge with African swine fever virus. J. Virol. 2014, 88, 13322-13332. [CrossRef] [PubMed]

109. Leitão, A.; Malur, A.; Cartaxeiro, C.; Vasco, G.; Cruz, B.; Cornelis, P.; Martins, C.L. Bacterial lipoprotein based expression vectors as tools for the characterisation of African swine fever virus (ASFV) antigens. Arch. Virol. 2000, 145, 1639-1657. [CrossRef] [PubMed] 
110. Leitão, A.; Malur, A.; Cornelis, P.; Martins, C.L. Identification of a 25-aminoacid sequence from the major African swine fever virus structural protein VP72 recognised by porcine cytotoxic T lymphocytes using a lipoprotein based expression system. J. Virol. Methods. 1998, 75, 113-119. [CrossRef]

111. Alonso, F.; Domínguez, J.; Viñuela, E.; Revilla, Y. African swine fever virus-specific cytotoxic T lymphocytes recognize the $32 \mathrm{kDa}$ immediate early protein (vp32). Virus Res. 1997, 49, 123-130. [CrossRef]

112. Stone, S.S.; Hess, W.R. Antibody response to inactivated preparations of African swine fever virus in pigs. Am. J. Vet. Res. 1967, 28, 475-481. [PubMed]

113. Mebus, C.A. African swine fever. Adv. Virus Res. 1988, 35, 251-269. [PubMed]

114. DETRAY, DE. African swine fever. Adv. Vet. Sci. 1963, 8, 299-333. [PubMed]

115. Bommeli, W. Preliminary study on immunization of pigs against African swine fever. In Proceedings of the CEC/FAO Research Seminar Held in Sassari, Sardinia, Italy, 23-25 September 1981. Report No.: EU8466.

116. Blome, S.; Gabriel, C.; Beer, M. Modern adjuvants do not enhance the efficacy of an inactivated African swine fever virus vaccine preparation. Vaccine 2014, 32, 3879-3882. [CrossRef] [PubMed]

117. Argilaguet, J.M.; Pérez-Martín, E.; Gallardo, C.; Salguero, F.J.; Borrego, B.; Lacasta, A.; Accensi, F.; Díaz, I.; Nofrarías, M.; Pujols, J.; et al. Enhancing DNA immunization by targeting ASFV antigens to SLA-II bearing cells. Vaccine 2011, 29, 5379-5385. [CrossRef] [PubMed]

118. Revilla, Y. Heterologous prime-boost vaccine strategy for ASF. In Proceedings of the 3rd Annual GARA Scientific Worshop, ANSES, Ploufragran, France, 6-8 September 2016; p. 24.

119. Lokhandwala, S.; Waghela, S.D.; Bray, J.; Martin, C.L.; Sangewar, N.; Charendoff, C.; Shetti, R.; Ashley, C.; Chen, C.H.; Berghman, L.R.; et al. Induction of Robust Immune Responses in Swine by Using a Cocktail of Adenovirus-Vectored African Swine Fever Virus Antigens. Clin. Vaccine Immunol. 2016, 23, 888-900. [CrossRef] [PubMed]

120. Lopera-Madrid, J.; Osorio, J.E.; He, Y.; Xiang, Z.; Adams, L.G.; Laughlin, R.C.; Mwangi, W.; Subramanya, S.; Neilan, J.; Brake, D.; et al. Safety and immunogenicity of mammalian cell derived and Modified Vaccinia Ankara vectored African swine fever subunit antigens in swine. Vet. Immunol. Immunopathol. 2017, 185, 20-33. [CrossRef] [PubMed]

121. Manso Ribeiro, J. Déclaration sur la vaccination contre la Peste Porcine Africaine à la XXXe Session Générale de 1'Office International des Epizooties. Bull. Off. Int. Epiz. 1962, 58, 1031-1040. (In French)

122. Petisca, N.J. Quelques aspects morphologiques des suites de la vaccination contre la peste porcine Africaine (virose L) au Portugal. Bull. Off. Int. Epiz. 1965, 63, 199-237.

123. Sánchez-Cordón, P.J.; Chapman, D.; Jabbar, T.; Reis, A.L.; Goatley, L.; Netherton, C.L.; Taylor, G.; Montoya, M.; Dixon, L. Different routes and doses influence protection in pigs immunised with the naturally attenuated African swine fever virus isolate OURT88/3. Antiviral Res. 2017, 138, 1-8. [CrossRef] [PubMed]

124. Sanford, B.; Holinka, L.G.; O’Donnell, V.; Krug, P.W.; Carlson, J.; Alfano, M.; Carrillo, C.; Wu, P.; Lowe, A.; Risatti, G.R.; et al. Deletion of the thymidine kinase gene induces complete attenuation of the Georgia isolate of African swine fever virus. Virus Res. 2016, 213, 165-171. [CrossRef] [PubMed]

125. O’Donnell, V.; Holinka, L.G.; Krug, P.W.; Gladue, D.P.; Carlson, J.; Sanford, B.; Alfano, M.; Kramer, E.; Lu, Z.; Arzt, J.; et al. African Swine Fever Virus Georgia 2007 with a Deletion of Virulence-Associated Gene 9GL (B119L), when Administered at Low Doses, Leads to Virus Attenuation in Swine and Induces an Effective Protection against Homologous Challenge. J. Virol. 2015, 89, 8556-8566. [CrossRef] [PubMed]

126. O’Donnell, V.; Holinka, L.G.; Gladue, D.P.; Sanford, B.; Krug, P.W.; Lu, X.; Arzt, J.; Reese, B.; Carrillo, C.; Risatti, G.R.; et al. African Swine Fever Virus Georgia Isolate Harboring Deletions of MGF360 and MGF505 Genes Is Attenuated in Swine and Confers Protection against Challenge with Virulent Parental Virus. J. Virol. 2015, 89, 6048-6056. [CrossRef] [PubMed]

127. Afonso, C.L.; Zsak, L.; Carrillo, C.; Borca, M.V.; Rock, D.L. African swine fever virus NL gene is not required for virus virulence. J. Gen. Virol. 1998, 79 Pt 10, 2543-2547. [CrossRef] [PubMed]

128. Neilan, J.G.; Zsak, L.; Lu, Z.; Kutish, G.F.; Afonso, C.L.; Rock, D.L. Novel swine virulence determinant in the left variable region of the African swine fever virus genome. J. Virol. 2002, 76, 3095-3104. [CrossRef] [PubMed]

129. Reis, A.L.; Abrams, C.C.; Goatley, L.C.; Netherton, C.; Chapman, D.G.; Sanchez-Cordon, P.; Dixon, L.K. Deletion of African swine fever virus interferon inhibitors from the genome of a virulent isolate reduces virulence in domestic pigs and induces a protective response. Vaccine 2016, 34, 4698-4705. [CrossRef] [PubMed] 
130. O’Donnell, V.; Holinka, L.G.; Sanford, B.; Krug, P.W.; Carlson, J.; Pacheco, J.M.; Reese, B.; Risatti, G.R.; Gladue, D.P.; Borca, M.V. African swine fever virus Georgia isolate harboring deletions of 9GL and MGF360/505 genes is highly attenuated in swine but does not confer protection against parental virus challenge. Virus Res. 2016, 221, 8-14. [CrossRef] [PubMed]

131. O’Donnell, V.; Risatti, G.R.; Holinka, L.G.; Krug, P.W.; Carlson, J.; Velazquez-Salinas, L.; Azzinaro, P.A.; Gladue, D.P.; Borca, M.V. Simultaneous deletion of the $9 \mathrm{GL}$ and UK genes from the African swine fever virus Georgia 2007 isolate offers increased safety and protection against homologous challenge. J. Virol. 2016, 91.

132. Abrams, C.C.; Goatley, L.; Fishbourne, E.; Chapman, D.; Cooke, L.; Oura, C.A.; Netherton, C.L.; Takamatsu, H.H.; Dixon, L.K. Deletion of virulence associated genes from attenuated African swine fever virus isolate OUR T88/3 decreases its ability to protect against challenge with virulent virus. Virology 2013, 443, 99-105. [CrossRef] [PubMed]

133. Enjuanes, L.; Carrascosa, A.L.; Moreno, M.A.; Viñuela, E. Titration of African swine fever (ASF) virus. J. Gen. Virol. 1976, 32, 471-477. [CrossRef] [PubMed]

134. De León, P.; Bustos, M.J.; Carrascosa, A.L. Laboratory methods to study African swine fever virus. Virus Res. 2013, 173, 168-179. [CrossRef] [PubMed]

135. Carrascosa, A.L. Methods for growing and titrating African swine fever virus: Field and laboratory samples. Curr. Protoc. Cell Biol. 2011. [CrossRef]

136. Krug, P.W.; Holinka, L.G.; O’Donnell, V.; Reese, B.; Sanford, B.; Fernandez-Sainz, I.; Gladue, D.P.; Arzt, J.; Rodriguez, L.; Risatti, G.R.; et al. The progressive adaptation of a Georgian isolate of African swine fever virus to vero cells leads to a gradual attenuation of virulence in swine corresponding to major modifications of the viral genome. J. Virol. 2015, 89, 2324-2332. [CrossRef] [PubMed]

137. Calzada-Nova, G.; Husmann, R.J.; Schnitzlein, W.M.; Zuckermann, F.A. Effect of the host cell line on the vaccine efficacy of an attenuated porcine reproductive and respiratory syndrome virus. Vet. Immunol. Immunopathol. 2012, 148, 116-125. [CrossRef] [PubMed]

138. Chitko-McKown, C.G.; Chapes, S.K.; Miller, L.C.; Riggs, P.K.; Ortega, M.T.; Green, B.T.; McKown, R.D. Development and characterization of two porcine monocyte-derived macrophage cell lines. Results Immunol. 2013, 3, 26-32. [CrossRef] [PubMed]

139. Lee, Y.J.; Park, C.K.; Nam, E.; Kim, S.H.; Lee, O.S.; Lee du, S.; Lee, C. Generation of a porcine alveolar macrophage cell line for the growth of porcine reproductive and respiratory syndrome virus. J. Virol. Methods 2010, 163, 410-415. [CrossRef] [PubMed]

140. McCullough, K.C.; Basta, S.; Knötig, S.; Gerber, H.; Schaffner, R.; Kim, Y.B.; Saalmüller, A.; Summerfield, A. Intermediate stages in monocyte-macrophage differentiation modulate phenotype and susceptibility to virus infection. Immunology 1999, 98, 203-212. [CrossRef] [PubMed]

141. Sanchez-Torres, C.; Gómez-Puertas, P.; Gómez-del-Moral, M.; Alonso, F.; Escribano, J.M.; Ezquerra, A.; Domínguez, J. Expression of porcine CD163 on monocytes/macrophages correlates with permissiveness to African swine fever infection. Arch. Virol. 2003, 148, 2307-2323. [CrossRef] [PubMed]

142. Hurtado, C.; Bustos, M.J.; Carrascosa, A.L. The use of COS-1 cells for studies of field and laboratory African swine fever virus samples. J. Virol. Methods 2010, 164, 131-134. [CrossRef] [PubMed]

143. Gallardo, C.; Soler, A.; Nieto, R.; Carrascosa, A.L.; De Mia, G.M.; Bishop, R.P.; Martins, C.; Fasina, F.O.; Couacy-Hymman, E.; Heath, L.; et al. Comparative evaluation of novel African swine fever virus (ASF) antibody detection techniques derived from specific ASF viral genotypes with the OIE internationally prescribed serological tests. Vet. Microbiol. 2013, 162, 32-43. [CrossRef] [PubMed]

144. Gallardo, C. In vivo testing of selected ASFV strains: Studies with attenuated strains in different cell systems, and the use of adjuvants. In Proceedings of the ASFORCE European Union project, Full Consortium Meeting (FCM), Cagliari, Sardegna, Italy, 21-22 October 2013.

145. Moennig, V. The control of classical swine fever in wild boar. Front. Microbiol. 2015, 6, 1211. [CrossRef] [PubMed]

146. Rossi, S.; Staubach, C.; Blome, S.; Guberti, V.; Thulke, H.H.; Vos, A.; Koenen, F.; Le Potier, M.F. Controlling of CSFV in European wild boar using oral vaccination: A review. Front. Microbiol. 2015, 6, 1141. [CrossRef] [PubMed]

(C) 2017 by the authors. Licensee MDPI, Basel, Switzerland. This article is an open access article distributed under the terms and conditions of the Creative Commons Attribution (CC BY) license (http:/ / creativecommons.org/licenses/by/4.0/). 